ADDRESS: Abraham P. Leech | Jamaica L.I.

Woodbury Thursday July 30

\title{
My friend
}

I feel but little in the humour for writing any thing that will have the stamp of cheerfulness. - Perhaps it would be best therefore not to write at all, and I don't think I should, were it not for the hope of getting a reply. - I believe when the Lord created the world, he used up all the good stuff, and was forced to form Woodbury and its denizens, out of the fag ends, the scraps and refuse: for a more unsophisticated race than lives hereabouts you will seldom meet with in your travels. - They get up in the morning, and toil through the day, with no interregnum of joy or leisure, except breakfast and dinner.-They live on salt pork and cucumbers; and for a delicacy they sometimes treat company to rye-cake and buttermilk. - Is not this enough to send them to perdition "uncancelled, unanointed, unannealed?"- If Chesterfield were forced to live here ten hours he would fret himself to death: I have heard the words "thank you," but once since my sojourn in this earthly purgatory. - Now is the season for what they call "huckleberry frolicks."-I had the inestimable ectasy of being invited to one of these refined amusements. I went. - We each carried a tin pail, or a basket, or a big bowl, or a pudding bag. - It was fun no doubt, but it cost me two mortal pounds of flesh, besides numerous remnants of my apparrel, which still remain, for what I know, on the briars and bushes. - Was n't it hot!-And then our dinner-our pic-nic dinner!-there's the rub!-Guess now what we had.-A broken-bowl half full of cold potatoes; three or four bones thinly garnished with dirty, greasy ham; a huge pie, made out of green apples, molasses, and buckwheat crust; six radishes, and a tin pan of boiled beans!! - And all this had to be washed down with a drink they called "switchell," a villainous compound, as near as I could discover, of water, vinegar, and brown sugar. - Our conversation, too, was a caution to white folks; it consisted principally, as you may imagine, of ethereal flashes of wit, scraps of Homeric and Italian poetry, disquisitions on science and the arts, quotations from the most learned writers, and suggestions on the speediest way of making butter.- Tim Hewlett vowed he ought to have a buss from Patty Strong; Patty modestly declined the honour. - A struggle was the result, in which Tim's face received permanent marks of the length of Patty's finger nails; and the comb of that vigorous young damsel lost some of its fair proportions. - It was a drawn battle. - At the conclusion of this performance, we gathered together our forces and the bowls, baskets, and pudding-bags 
aforesaid, and returned home; for my part feeling "particularly and peculiarly kewrious" from the weight of amusement.-

I am much obliged for the paper you sent me. - Write soon. - Send me something funny; for I am getting to be a miserable kind of a dog; I am sick of wearing away by inches, and spending the fairest portion of my little span of life, here in this nest of bears, this forsaken of all Go[d]'s creation; among clowns and country bumpkins, flat-heads, and coarse brown-faced girls, dirty, ill-favoured young brats, with squalling throats and crude manners, and bog-trotters, with all the disgusting conceit, of ignorance and vulgarity. - It is enough to make the fountains of goodwill dry up in our hearts, to wither all gentle and loving dispositions, when we are forced to descend and be as one among the grossest, the most low-minded of the human race. - Life is a dreary road, at the best; and I am just at this time in one of the most stony, rough, desert, hilly, and heartsickening parts of the journey.- But Time is the Great Physician who cures, they say, our ills of mind and body. -I pray the fates he may rid me of my spleen ere long

W.W.

ADDRESS: Abraham P. Leech | Jamaica, L.I.

“Devil's den," Tuesday Aug. 11

My friend,

Why the dickins did n't you come out to the whig meeting at the court house, last Saturday week?-I went there, with the hope of seeing you and one or two others, as much as for any thing else. - I dare say you would have been much gratified; at any rate you would have been astonished, for the orator of the day related facts, and cut capers, which certainly never before met the eye or ear of civilized man. - Just before sun down the performance concluded, and starting from the C[ourt] $\mathrm{H}$ [ouse] I was overtaken by a most impertinent shower, which drenched me to the skin; probably all the whig enthusiasm generated on that occasion was melted down again by this unlucky shower, for we passed loads of forlorn gentlemen, with draggle-tailed coats, crest-fallen hats, and sour-looking phizzes. - The mighty patriotism they felt was drowned by a tormenting slipperiness of coat, shirt, and pantaloons. -

Were you ever tried? - I don't mean tried before Squire Searing or Judge Strong for breach of promise or theft; but tried as they try mutton fat, to make candles of - boiled down-melted into liquid grease? - tried as they try martyrs at the stake? - If you havn't-I have. - The scene was "Huckleberry plains," the day Friday last-the time, from twelve 
o'clock, M. until 31/2 P.M.-You see I'm particular.-The awful occasion impressed indelibly upon my memory every agonizing moment of that infernal excursion. It was what the ladies and gentlemen of this truly refined place called a party of pleasure. - Yes; it was delightful; fun to the back-bone: but it cost me a sun-burnt face and neck, from which the skin is even now peeling, and four mortal pounds of flesh which ran off in a state of dilution from my body. - The sun poured down whole lumps of red hot fire-not a tree, not a shed to shelter us from the intolerable glare. - I gave you in my last some account of my first "huckleberry frolick," but this beats it all hollow.-I can only wonder why I was such a thundering fool as to try it again.-

How are you all in Jamaica? - What is the news? - Do you have any games at Twenty Questions? -Does "our portrait" yet remain in the condition of the southern banks? - O, how I wish I was among you for a few hours: how tired and sick I am of this wretched, wretched hole! -I wander about like an evil spirit, over hills and dales, and through woods, fields, and swamps. In the manufactory of Nature, the building of these coarse gump-heads that people Woodbury, must have been given to some raw hand; for surely no decent workman ever had the making of them. - And these are the contemptible ninnies, with whom I have to do, and among whom I have to live.-O damnation, damnation! thy other name is school-teaching and thy residence Woodbury.-Time, put spurs to thy leaden wings, and bring on the period when my allotted time of torment here shall be fulfilled.-Speed, ye airy hours, lift me from this earthly purgatory; nor do I care how soon ye lay these pudding-brained bog-trotters, amid their kindred earth. -I do not believe a refined or generous idea was ever born in this place; the whole concern, with all [i]ts indwellers, ought to be sunk, as Mosher says, "to chaos." Never before have I entertained so low an idea of the beauty and perfection of man's nature, never have I seen humanity in so degraded a shape, as here.-Ignorance, vulgarity, rudeness, conceit, and dulness are the reigning gods of this deuced sink of despair. - The brutes go barefoot, shave once in three weeks, call "brown cow" "breown ke-ow;" live on sour milk, rye bread, and strong pork; believe L[ong] I[sland] sound and the south bay to be the ne plus ultra of creation; and the "gals" wear white frocks with red or yellow waist-ribands. -

Think, my friend, think on all this; and pray nightly for my deliverance from this dungeon where grace or good-breeding never were seen, and from whence happiness fled shrieking twenty years ago.Farewell-and may the blessings of hope and peace, the sunshine of a joyous heart, never be absent from you.-May the bloom of health glow on your features, the tide of joy swell in your heart, and care and grief be strangers to your dwelling

W. Whitman 
Purgatory Fields, Wednesday Aug 19.

Have you never heard people advance the opinion that earth is man's heaven or hell, according as he acts or is situated, good or evil? -I believe that doctrine; or, at any rate, I believe half of it, as the man said when he was told that his wife had twins. - That this earthly habitation is a place of torment to my miserable self, is made painfully evident every day of existence. - Fate never made a place where dulness perched on every tree, obtuseness located himself on every hill, and despair might be seen "sittin on a rail," every ten yards, as completely as in this cursed Woodbury. - Woodbury! appropriate name!-it would-bury me or any being of the least wish for intelligent society, in one year, if compelled to endure its intolerable insipidity, without the hope of relief.-Before many weeks, I expect to be in the condition of those pleasant beings of whom it is said "They are nothing but skin and bone."-You do not know, my friend, nor can you conceive, the horrid dulness of this place.-Making money, plodding on, and on, and on; raising ducks, carting dung, and eating pork, are the only methods of employment that occupy the Woodbury animals. - And as avocations of this nature never met my fancy in any great degree, you may easily imagine what an interesting situation I am in.-

I have eaten my dinner since the last line over leaf was written; but I don't know that I felt any the better as to good-humour. - What do you think I had for dinner?-Guess, now.-Beef?-no.-Mutton?-No.Pot-pie? No. - Salad and iced champagne? - No, no, no.--I'll tell you in the order that it was put up, or rather put down.-Firstly, two cold potatoes, with the skins on, one of said potatoes, considerably nibbled in a manner which left me in doubt whether it had been done by the teeth of a mouse or the bill of a chicken; secondly three boiled clams, that had evidently seen their best days; - thirdly a chunk of molasses cake made of buckwheat flour; - fourthly, a handful of old mouldy pot-cheese, with a smell strong enough to knock down an ox; - fifthly, and lastly, two oblong slats of a mysterious substance, which I concluded, after considerable reflection, must have been intended for bread; - this last would undoubtedly [have] been very interesting either to a Grahamite, or to one fond of analyzing and studying out the nature of the mineral kingdom.-Was n't this a feast for an Epicure? - Think, $\mathrm{O}$ thou banquetter on good things, think of such an infernal meal as that I describe, and bless the stars that thy lot is as it is.-Think, moreover, that this diabolical compound was wrapped up in [a] huge piece of brown paper, and squeezed into a little tin pail, which said pail, being minus in the matter of a handle or bail, had to be carried by a tow string 
instead!-Imagine to yourself, now, that you see me toting along with such an article as I [have] been describing.-Don't I cut a pretty figure? $\mathrm{O}$, ye gods, press me not too far-pour not my cup too full-or I know what I shall do.-Dim and dreadful thoughts have lately been floating through my brain.-The next you hear of me, I may possibly be arraigned for murder, or highway robbery, or assault and battery, at the least. - I am getting savage. - There seems to be no relief. - Fate is doing her worst. - The devil is tempting me in every nook and corner, and unless you send me a letter, and Brenton remits me an armful of news, there is no telling but what I shall poison the whole village, or set fire to this old school-house, and run away by the light of it. -

I suppose all "your folks" are the same as usual, and that Jamaica is "situate, lying, and being" as in November last. - But do for pity's sake forward something or other to me soon, in the shape of mental food. - May you grow fat with peace and good cheer. - May the sun of peace warm you, and the dews of prosperity fall thick around your path. - May the Fates be busy with cutting other threads than yoursand may kind fingers shield you in the hour of death. - Adieu.-

Walter Whitman

.04 To Abraham Paul Leech

8.26. [1840]

Wednesday August 26.

Dearly beloved - Moved by the bowels of compassion, and pushed onward by the sharp prickings of conscience, I send you another epistolary gem. - For compassion whispers in mine ear that you must by this time have become accustomed to the semi-weekly receipt of these invaluable morsels; and therefore to deprive you of the usual gift, would be somewhat similar to sending a hungry man to bed without his supper.-Besides, conscience spurs me to a full confession; which generally operates on me like a good dose of calomel on one who has been stuffing immoderately, making a clear stomach and comfortable feelings to take the place of overburdened paunch and rumbling intestines. Excuse the naturality of my metaphor.-

Speaking of "naturality" reminds me of the peculiarities that distinguish the inhabitants, young and old, of this well-bred and highly romantick village. - For instance, I was entertained the other day at dinner, with a very interesting account by the "head of the family," (families of fourteen or fifteen, in these parts, have but one head amongst them) of his sufferings from an attack of the gripes; how he had to take ipecachuana, and antimonial wine; the operation of those substances on his stomach; the colour and consistency of the fluids and solids ejected from the said stomach; how long it was before epsom salts could be 
persuaded to take pity on his bowels; with many and singular concomitant matters, which, you may well imagine, contributed in a high degree to the improvement of my appetite. - I frequently have the felicity of taking my meals surrounded by specimens of the rising generation.-I mean little young ones getting out of bed; and as "to the pure all things are pure," the scene of course is in a high degree edifying to my taste and comfort. -

We have had delightful weather out here for the past few days. The sun at this moment is shining clear, the cool breeze is blowing, the branches of the trees undulate, and all seems peace and joy but the mind - the mind, that strange, unfathomable essence, which is, after all, the main spring of our happiness here.-My period of purgation is almost up in these diggin's. - Thank the pitying fates! in two weeks more I shall wind up my affairs, and with tears in my eyes bid a sorrowful adieu to these hallowed precincts. - Shady walks, venerable old schoolhouse, dismantled farms, innocent young ideas-all-all-will I look upon for the last time.-But I must stop-I cannot carry out the affecting thought any farther. - My heart swells, and my melting soul almost expires with the agonizing idea. - Let me hold out a little longer, O, ye powers.!

How are politicks getting along down your way? - Is hard cider in the ascendant; or does democracy erect itself on its tip-toes and swing its old straw hat with a hurrah for "Little Matty?" Down in these parts the people understand about as much of political economy as they do of the Choctaw language; I never met with such complete unqualified, infernal jackasses, in all my life.-Luckily for my self-complacency they are mostly whigs. - If they were on my side of the wall, I should forswear loco-focoism, and turn traitor in five minutes. - We had a swinging meeting at the Court house, last Saturday. - I tell you what, our speakers went as far ahead of "the fat gentleman in striped trousers," as a Baltimore clipper does beyond a North River dung boat. - There was no 'kimparysun.'

Can't you look round Jamaica and find out whether they dont want a teacher somewhere, for a quarter? - I shall probably drop down there in the course of a week or two, and stay a day.-See to it, and oblige me. - I hope that holy angels will have you in keeping, and that the fragrance of plenty and the musick of a pleasant heart, will never be foreign to you. - Sweet blossoms bloom beneath your eyes, and the songs of birds gladden your hearing! - Farewell. -

Walter Whitman

.04.5 To Abraham Paul Leech

9.9. [1840]

My dear L-I perform the thrice-agreeable office of informing you 
that my purgatory here is just finishing. - In a few days more I shall be unbound and unloosed.-At present I think it improbable that I shall pay any visit to Jamaica, though I should like to see my friends there. - Write to me on Friday, by the cars, or on Tuesday next, by the baker: after that time I shall not be here to "receive communications." $\mathrm{O}$, how my spirit springs and grows elastick at the idea of leaving this diabolical, and most [p]articularly cursed locality!-Shades through which I have wandered; orchards that I have plundered; old schoolroom, dirty-faced urchins; and moth-eaten desk, I bid ye all a long farewell. - Pork, cucumbers, and buckwheat bread, we must part, perhaps forever!-Solemn thought! Rye-sweetcake, sour milk, and "scented" fish-ye dear companions of the past summer-alas! the mouth that has known you, will know you no more.-

Dont forget to write on Friday, if you can. - Brenton will send me a package at that time, and your letter can be slipped in like a knife.State how Abel is; and indite the news generally. May the Saints bless you; and may Peace never get out of humour and cut your acquaintance.

Wednesday afternoon Sept. 9- W. Whitman

\section{.04.20 To Abraham Paul Leech}

3.25. [1841]

By what Overacre would call an "exceedingly natural and extensive concatenation of radical causes," I begin thinking, now that I sit down to write to you, of the time and place that I used to hail from some eight or nine months ago. - You no doubt remember those precious missives that sprang almost diurnally from my teeming hand at Purgatory Place.-But that Place! O, it makes my nerves quiver as I think of it. -Yes, anathema! anathema, curse, curse, upon thee thou fag end of all earthly localities, infernal Woodbury! But I fear I am getting warm.-Let me push the subject no farther. - The fact is, the most distant mention of that diabolical region, that country of buckwheat dough-nuts, and pot-cheese, and rye sweet-cake, always makes me fall a swearing. - Faugh!

Have you never in your travels come across a village where some half dozen principal characters seemed to give a colour and tone to the whole place? - Of such a nature is this Whitestone, which your servant now irradiates with the benign light of his countenance.-The principal feature of the place is the money making spirit, a gold-scraping and a wealth-hunting fiend, who is a foul incubus to three fourths of this beautiful earth.-Unfortunately, too, these "leaders" here, set but a poor example to the rest as regards their strict adherence to the domestick ties and institutions which old Madame Custom has planted and nourished and made at last so deeply rooted among us. - Enough of 
this however.-Do not think I am going to fall into the splenetic, fault-finding current, on which those Woodbury documents were set afloat. -

I am quite happy here; and when I say this, may I flatter myself that some chord within you will throb "I am glad to hear that?" - Yes, as far perhaps as it falls to mortal lot, I enjoy happiness here.-Of course, I build now and then my castles in the air. -I plan out my little schemes for the future; and cogitate fancies; and occasionally there float forth like wreaths of smoke, and about as substantial, my day dreams. - But, take it all in all, I have reason to bless the breeze that wafted me to Whitestone.-We are close on the sound. - It is a beautiful thing to see the vessels, sometimes a hundred or more, all in sight at once, and moving so gracefully on the water.-Opposite to us there is a magnificent fortification under weigh. - We hear the busy clink of the hammers at morn and night, across the water; and sometimes take a sail over to inspect the works, for you know it belongs to [the] U.S.-

My quarters are quite satisfactory too as regards boarding. - One of the windows of my room commands a pleasant view of the sound.Another looks to the eas[t] and the great round face of the sun[;] he comes along in the morning, almost seems to kiss me with a loving kiss. - I am generally dressed and ready to receive him at his first appearance. - This said room of mine is something that I much value. It is my sanctum sanctorum, which profane foot invadeth not.-Its hallowed precincts are forbidden ground to every she in the house, except for absolutely necessary entrances, which concern the vital well-being of its lord.-

I hope this will find you enjoying health and peace. $-\mathrm{O}$ that I were Napoleon that I might load the heads of my friends with golden coronets. - My best wishes I waft to you, wrapped up and sealed with a wafer. - May your shadow never be less. - Adieu

Thursday night $\mid$ March 25 Walter Whitman.

\section{Old Friend}

I received your welcome epistle some weeks since, and was pleased to find you had not forgotten me.-

I am still in this whereabouts, and here I shall probably remain for some time to come. - You may imagine how fortunate this decision of mine is for the people here.-Of course as long as these diggin[gs] are irradiated by the presence of your humble servant, a double amount of spendour in things spiritual, moral, and intellectual, is bestowed upon the residents thereof.-

I see by the papers that Overacre has opened a "Children's 
Retreat," for the practice of "Home Education." If he succeeds probably the "Corruscations of the lambent flame" will set your South Bay in flames. - Sincerely, however, I think there is much more in that man's system and in his brain too, than is appreciated by the people of your mam[m]on-and-aristocracy-worshipping village. - Tell him so for me.God bless you

W Whitman

.07 To Abraham Paul Leech

10.21. [1841?]

I write a word to you in haste. Three weeks since I returned from near Ithaca, whither I went after leaving Jamaica. I was completely disappointed in my exp[ecta]tions there. $-\mathrm{I}$ am now in the city, but as Mr. Meeks by whom I send this is in hast[e] I can write no more than to say that in the course of a few days I intend paying a visit to you all at Jamaica-

Thursday afternoon | Oct $21-$ Walter Whitman

.08 To Abraham Paul Leech

[Late 1841?]

Friend Leech

How d'ye do? - I have quite a hankering to hear from, and see Jamaica, and the Jamaicaites. - A pressure of business, only, has [pr]evented my coming out among the "friends of yore," and the familiar places which your village contains. - I was an hour in your village the other day, but did not have time to come up and see you. -I think of coming up in the course of the winter holidays. - Farewell, - and dont forget writing to me, through the P. O.-

May your kind angel hover in the invisible air, and lose cite of your blessed presence never

W Whitman 


\section{Dear Madam}

Your generous remittance of $\$ 75$ for the wounded \& sick was duly received by letter of 21 st $\&$ is most acceptable. So much good may be done with it. A little I find may go a great ways. It is perhaps like having a store of medicines-the difficulty is not so much in getting the medicines, it is not so important about having a great store, as it is important to apply them by rare perception, honest personal investigation, true love, \& if possible the inspiration \& tact we in other fields call genius.

The hospitals here are again full, as nearly all last week trains were arriving off \& on from front with sick. Very many of these however will be transferred north as soon as practicable.

Unfortunately large numbers are irreparably injured in these jolting railroad \& ambulance journeys, numbers dying on the road.-

Of these come in lately, diarrhea, rheumatism \& the old camp fevers are most prevalent. The wrecks in these forms of so many hundreds of dear young American men come in lately, are terrible, \& make one's heart ache.

Numerically the sick are the last four or five weeks becoming alarmingly greater, \& in quality the cases grow more intense. I have noticed a steady deepening of this intensity of the cases of sickness, the year \& a half I have been with the soldiers. Hospital accommodations here are being extensively added to. Large tents are being put up, \& others got ready.

My friend, you must accept the men's thanks, through me. I shall remain here among the soldiers in hospital through the summer, with short excursions down in field, \& what help you can send me for the wounded \& sick I need hardly say how gladly I shall receive it \& apply it personally to them.

Walt Whitman

address) Care Major Hapgood | paymaster U S Army | Washington D C 
164.1.1 To Anson Ryder, Fr.

ATTORNEY GENERAL'S OFFICE,

Washington, Aug. 15, 1865.

Dear Anson,

As there is a sort of lull and quiet for a short time in my work, I will improve the opportunity to write to you, dear friend. In this office, I am in the part where the Pardons are attended to. There is a perfect stream of Rebels coming in here all the time to get pardoned. All the Southerners that are worth more than $\$ 20,000$ in property, have to get special pardons, \& all who have been officers of the rank of Brig. Gen'l, or upwards, the same. Many old men come in here, and middle-aged \& young ones too. I often talk with them. There are some real characters among them - ( \& you know I have a fancy for any thing a little out of the usual style)-

Quite a good many women come up to Washington, \& come to this office, about their pardons - some old, some young-all are drest in deep black. Then there are bushels of applications arriving every week by mail. When they are recommended by the Provisional Governors, or some well known Union person, they get their papers-Many have got their papers-but nearly all are waiting for the President's signature-I should think 3 or 4000 . He is n't in any hurry to sign them.

I was down at Armory Square Sunday. Dr. Smith said he had rec'd a letter from you, \& was just going to answer it. I went awhile in Ward I, among the rebels - they are in a wretched condition, \& nobody goes among them. I shall go in \& see Hiram in a day or so. I am in good health, \& generally have easy times-As half the force of clerks here are off on leave, I some days have a pressure $-\&$ that is the case lately. But I shall be careful to make it up. We have pleasanter weather here the last ten days-quite cool mornings \& nights.

My dear friend, I am sorry you could not have been with me for a day or two before you left Washington, as it may be we shall not meet again. But you must not forget me, for I shall not you. Write to me from time to time, Anson, \& I will you too. The picture you shall have-As I am writing this at the office, otherwise I would enclose one of the card photographs in it - they are up at my room-I will send one in my next. Write how your leg is - Give my best remembrances to Wood-he is a good man \& I hope he will prosper through life-When you write, direct to me, Attorney General's Office, Washington, D. C.

Blue coats here are getting quite scarce. Your letter of 9 th came safe, \& was welcome. I envy you the pure fresh country air \& healthy influences, \& I doubt not, fine scenery \& quiet. When you write tell me 
about the neighborhood-where is Cedar Lake, \& what kind of place?Well Anson I must close. God bless you, my loving soldier-boy, now \& always.

Walt Whitman

Wednesday morning, 16th Aug.

Anson, as I neglected to send this yesterday, I have brought down a couple of little pictures \& enclose them, after all. But you shall have a larger \& better one, dear son,-I will have it prepared \& fix some way to send it to you. They have commenced breaking up Armory Square. The picture in shirt sleeves was taken in 1854-You would not know it was me now, but it was taken from life \& was first-rate then. Anson, when you write tell me all particulars of yourself, folk's place $\&$ about Wood, \&c.

Your true friend, W. W.

276.4 To W. O. Baldwin

ATTORNEY GENERAL'S OFFICE, Washington, March 4, 1868

My dear Mr. Baldwin:

I write in reference to a friend of mine, Dr. Charles H. Bowen, of this city, who will soon call upon you personally. He seeks the appointment of Surgeon to the Metropolitan Police here. I have known Dr. Bowen for several years. He was a volunteer U. S. Army surgeon during the war, \& was considered one of the best. I can fully join in the same testimony, as he treated, as physician or surgeon, many a case under my own eye, for days \& even months. He is a good Union man, of full professional experience, gentlemanly manners, temperate, in the prime of life-\& I have more than once, when watching his treatment, called him an intuitive physician.

I most strongly recommend him as the right man, \& one without deficiency in any of the qualifications needed for the place of Police Surgeon.

Should you wish it, I will be glad to wait upon you, to testify further regarding Dr. B.

I. send you, dear sir, my friendliest respects \& well wishes, Walt Whitman 
431 Stevens st. | cor West. | Camden, | N. Jersey. |

May 7, '75.

Robert Carter,

Dear Sir,

Thinking that possibly I might be itemised or briefly biographised in the Cyclopoedia I thought I would send you, (or to Mr. Dana,) the accompanying sketch-some authentic statistics, (as I find I am beginning to be noted, \& they make sad work of it sometimes.) Leaving of course the whole thing in your own hands, I should like you to get the statistics, the fact-basis right-(\& should you think proper can be further consulted here, or proof sent, \&c.)-

My book Leaves of Grass, as now printed, is in its permanent form - my other Vol. of equal size, Two Ruvulets, (i. e. of Real and Ideal) will comprise all my other writings, Prose $\mathcal{E}$ Verse, \& is now being put in type. I am still prostrated with cerebral \& liver affection but work occasionally.

Walt Whitman

\subsection{To an Unidentified Editor}

431 Stevens st. | cor West. | Camden, | N. Jersey, | Aug 9, '75.

My dear Mr. Editor,

Would this piece be available for the Magazine? - The price is $\$ 100$. Walt Whitman

697.5 To an Unidentified Correspondent

[12.25.] 1875

Christmas, 1875.

best respects, love, \&

thanks of

Walt Whitman 
431 Stevens st. | cor. West | Camden | N. Jersey | U S America

My dear friend,

Enclosed I send you a piece printed here to give a true statement of the situation $-\&$ which I should be well satisfied to have printed in Britain.

I ought to have written you before. I have read your "Shakspere," \& ought to have thanked you for it. I find it full of vitality $-\&$ suggestiveness on themes that might be supposed exhausted years ago-but are not at all exhausted.

As I write, I am feeling pretty comfortable-much the same as for the last two years-no worse. John Burroughs was here with me last week. He is well. I have just written to W. M. Rossetti, Ev sent him this printed slip too.

I sent you a paper with my little book circular ten days or so since. $M$. D. Conway had called upon me. He is a good \& intellectual man, but I don't think I either get hold of him, nor he of me, at all.

My friend, I must still put off for another letter, some things I have had in my mind for months to say to you-Your letters past - What John Burroughs told me-(\& your Shakspere book too)-have grafted you more on my good will \& memory than you perhaps know-I write in haste.

Walt Whitman

864.5 To Sidney Lanier

5.27. [1878]

ADDRESS: Sidney Lanier | 33 Denmead Street

Baltimore | Md:. POSTMARK: Camden | May | 27 |

N. J.

Camden New Jersey

May 27-I have to-day sent by mail, same address as this card, my Volume Leaves of Grass - Please notify me (by postal card will do) soon as it reaches you safely

Walt Whitman 
1309 Fifth av. 2d house south | of 86th street | New York

June 26 P M

Dear John \& 'sula

I got in all right before sundown-Still keep well, ( $\&$ all the better for my Esopus trip-\& the berries, \&c.)

Yesterday went on a sail down the bay to Sandy Hook with some Sorosis ladies \& only a few men - a real sea-sail, sea-breeze \&c-(I went up in the Pilot house most of the time with the pilots)- had dinner on board-I enjoyed it, but was pretty tired-got in before dark-

Shall stay here a few days longer-find it hard to get away-John, I send you a slip cut from the Tribune-

Walt

\subsection{To Fosiah Child}

ADDRESS: Josiah Child | Care Trübner \& Co. |

57 Ludgate Hill | London England

Camden New Jersey | U S America | June 27'79

Dear Mr Child

Upon coming back here I found the "Tobacco Plants" all rightThanks to you for them, ( \& many favors \& attentions) - I rec'd about a week ago the P O draft for $\$ 15.20$ from Mr Fraser, for my article, \& immediately notified $\mathrm{Mr}$ F.

I am well, for me-am taking a rest from my three months' visit to New York-our heated term now here.

Walt Whitman

980.5 To the Reverend Minot Fudson Savage

Camden New Jersey Nov: 4 '80

Yours rec'd with enc: - thanks - I forward my two Vols: to-day by mail, same address as this card-Will you please send me a postal soon as they reach you safely notifying me?

Walt Whitman 
431 Stevens Street | Camden New Jersey April 9 '81

My dear Miss Gilder

Thanks for the slips of No: 2 , which have duly come. Also the paper-I believe I shall have to decline writing about Victor Hugo, for you - don't know enough about him - (the article in to-day's Critic seems to me to have it about right) -

I send you two more batches of Notes-

I am going on to Boston middle of next week-return forthwith.

Walt Whitman

Send on the proofs as before-Have you ever thought of asking Wm. D. O'Connor of Washington, Life Savings Service Bureau, to write for you?

1021.6 To Albert D. Shaw

431 Stevens Street | Camden New Jersey U S America | April 9 '81

Dear Sir

Yours of March 26th rec'd. I send my two Vols: Leaves of Grass and Two Rivulets, by mail same address as this note. The price is $\$ 10$, which please remit by p.o. order, if convenient. You will find autograph in the Vols:

Walt Whitman

1073.5 To feannette L. Gilder 11.21. [1881]

431 Stevens Street | Camden New Jersey | Nov: 21

Right after correction carefully, please send me five sets of proof slips of this $-\&$ then on publication ten copies of paper.

The price if agreeable is $\$ 16-$

Walt Whitman 
ADDRESS: Talcott Williams | Daily Press office |

Cor: 7th \& Chestnut Strs: Philadelphia.

POSTMARK: Philadelphia $\mid \mathrm{Pa}$. June $|29|$

$1882 \mid 12 \mathrm{M}$.

Ferry-Delaware-noon June 29

Your note rec'd-I send you at a venture the earliest data $\&$ facts, so you can keep posted, \& make whatever mention, if any, accuratelybut would rather not myself only my name appear as furnishing, or giving authority for the statement - only whatever I send you I vouch for-

There is a little nest of most malignant enemies to me personally \& to L. of G. in Boston (and in New York also) who are determined to press the matter to an extreme. The P $\mathrm{M}$ in Boston has lately been captured by them. I hear that a formal demand has been made on the $P$ $M$ General at Wash'n to exclude $L$ of $G$ from the mails under the Comstock "obscene" law, \& that it is now before that officer-perhaps has been already decided.

In connection let me state that I am putting a new book in type, my Prose Works, called Specimen Days, E Collect, about 380 pages-gives a lot of random typical days, diary fashion, during my life $-\&$ then swoops pell mell my past literary papers, essay \&c. in the Collect (like fish in a net) - is to be a companion Vol to my Poems - Is to be pub. by Rees Welsh \& Co: 23 South 9th st. Phila, who are also to be the publishers henceforth of $\mathrm{L}$ of $\mathrm{G}$, which they will put freely in the market in ten or twelve days - exactly as squelched in Boston-(a \$2 Vol. same as the late Osgood ed'n.)-My friends in this conjuncture-(I consider you one of them, you blew the first blast, as clear \& loud as ever trumpet pealed)-are, among others, Wm D O'Connor, Life-Saving Service Bureau, Washington, Dr R M Bucke, London, Ontario, Canada, The Springfield Republican-Cambridge Chronicle-Sylvester Baxter on the Boston Herald-\&c-

Walt Whitman

\subsection{To fohn Burroughs}

Camden N J Dec: 15 '82

Dear friend

Yours of 12th recd. I sent Dowden's letter soon after getting it, to O'Connor, with written request on it to send to Dr Bucke, with similar request to him to send to you -I supposed you had it a fortnight or more 
ago. I yesterday wrote to O'Connor about it, asking him to forward to you directly. The same round (to $\mathrm{O}^{\prime} \mathrm{C}$ - to Dr. B and to you) to a long notice of "Specimen Days" in the "Academy" by Dowden-I supposed you had rec'd both-I fancy you certainly will get them-perhaps you have already-

I have those Emerson vols (just as you lent them to me over 10 years ago) boxed up \& stored with other traps in Washington at the house of old Mr Nash, Peter Doyle's uncle- Shall surely have the boxes here before long, (or go on \& overhaul them) \& if that will do-will certainly see the vols are sent to you-

I am quite over my bad spell of a month ago-havn't made any move from Camden yet, but shall- "Specimen Days" moves pretty sluggishly - no great demand - L of G. better, but by no means what was anticipated-

I am more than satisfied, however-every thing might have been so much worse $-\&$ best of all, in my mind, on looking over L of G. as it now stands-I don't worry about how much better it ought to be, but thankful it is as well as it is - I am content to let it rest, to let it go as it is, without the least wish to meddle with it any more, (a feeling I havn't had before, but now certainly settled.)

I have a criticism on Burns in to-morrows 'Critic'-Love to 'Sula and the dear little fellow-(I bear you all more in mind than you think for) - I hear there is a notice of L of G. in Dec. "Nineteenth Century"Walt

John, I shall return that $\$ 100$ I borrowed shortly-

\subsection{To Charles Scribner's Sons}

Germantown Phila:

Aug: 25 '83

Charles Scribner's Sons

Dear Sirs

I hereby authorize you to print the pieces in your volumes as requested in the foregoing.

Walt Whitman 
1260.5 To the Editor, The Philadelphia Record

431 Stevens street | Camden New Jersey U S America |

Jan: 19 ' 84

Dear Sir

This item-

A new edition of Walt Whitman's works, has been brought out in London, with an appendix containing the opinions of George Eliot, Ruskin, Tennyson, Swinburne, Rossetti and others concerning Whitman.-

is printed in the papers here of late-I suppose fictitious informationBut I thought I would write to you to ask if you know or have heard. Is it not a mistake for the Wilson \& McCormick edition, (from the plates here)? - But that has no "appendix" as mentioned above.

I am well as usual-Dr Bucke was down from Canada a short time since to see me. I get the "Record" from your establishment, \& thank you.

Walt Whitman

\subsection{To Thomas G. Gentry}

Camden New Jersey | Feb. 11 '84

Dear Sir

I am entirely willing you should print the piece, as you request-

Walt Whitman

1269 To fohn H. Fohnston

[3.27. 1884]

ADDRESS: J H Johnston | Jeweler 150 Bowery cor

Broome | New York City. POSTMARKs: Camden | Mar | $27 \mid$

12 AM | 1884 | N.J.; P.O. | 3-27-84 | 5 | N.Y.

328 Mickle street Camden | New Jersey

Letter and the One Hundred rec'd-Thanks-(comes very acceptable)-I am moving in-in two or three days I will have the carpenter box the picture properly, \& will send it $-\mathrm{I}$ am feeling pretty fair. 
328 Mickle Street | Camden New Jersey | June 12 '84

\title{
Dear Sir
}

I send you, same mail with this, a copy of the $\$ 3$ autograph edition of Leaves of Grass- yours of some weeks since sending \$2 was received-leaving $\$ 1$ due which please enclose in letter \& send me here.

\section{Walt Whitman}

\subsection{To P. F. O’Shea}

\author{
ADDRESS: P J O'Shea | Attorney \& Counselor | \\ 163 Randolph Street | Chicago Ill:. \\ POSTMARK: (?) | 430 PM | (?) | N.J.
}

328 Mickle street | Camden New Jersey | Dec. 131886

Thanks for your kind letter \& the nice gift-the $\$ 10-$ which has safely reached me, $\&$ is opportune-

Walt Whitman

I did not know of any "pirated edition" in Chicago-Do you mean that some one has printed the book surreptitiously there- $\&$ is or has been selling it?

1499.1 To Fohn Hay

328 Mickle street | Camden New Jersey March 10 '87

My dear John Hay,

I send the two sets of books you requested-Also a MS copy of "My Captain"-also a little Vol: containing my Dartmouth College Commencement-Poem-address in 1872 . The sets are $\$ 10$ cash, \& the MS $\$ 2-\$ 22$ altogether, which please remit me by post office order.

I am comfortable enough here in a democratic way, \& in good heart, but physically wreck'd \& paralyzed. O'Connor is now in Southern California, sick - I send you my remembrance love \& thanksWalt Whitman

the parcel goes by express 


\subsection{To Deborah Stafford Browning}

ADDRESS: Mrs: Debbie Browning | Care of Will Goldy | p o box $91 \mid$ Topeka Kansas.

POSTMARK: Camden, N.J. | Apr $19 \mid 8$ P M | 87.

Camden N J-April 19 '87

I was down at Glendale Sunday-all well-all ab't as usual-Your father better, his back hurts some, but I think it will pass over-Ed was away-Harry has been here to-day-is getting along favorably-I have been to New York-Send you a paper with acc't-Love to Ruth, [Jo?], and all-

Walt Whitman

\subsection{To Louisa Orr Whitman}

Camden | Saturday afternoon | April 30 '87

Dear Lou

Mrs: Goodenough has been here \& I have paid her-enclosed is receipt - I continue ab't half and half in feeling $\&$ health

Mrs: G. says Ed is well-I rec'd a note from my sister H[annah] when I was in N Y at the Hotel-all ab't as usual with her-

Walt Whitman

\subsection{To Thomas fefferson Whitman}

ADDRESS: Thos: J Whitman | 2437 2d Carondelet Av: |

St Louis Missouri. POSTMARK: Camden, N.J. |

Jun 1[3] | 8 P M |'87.

Am pretty well to-day (after being under the weather the past week) - Nothing new in my affairs - I am getting [a]long comfortablyShall soon [s]end dear J[essie] a new piece of mine in a magazine-There is a Boston [s]cheme afoot to get me a little house [in] the country or seashore-

Walt Whitman 


\subsection{To Fames Hunter}

ADDRESS: James Hunter | Vienna | Virginia.

328 Mickle Street, Camden, New Jersey

Friday Eve, June 22, '88

Dear friend - and all your folks, all the family - I have been very ill for over a fortnight and still badly and weak yet-not yet quite definite - but the Doctor favors the probability - The heat is great-but in pulse and appetite things help me along-also in good spirits. Good remembrances and affection to you all-

\section{Walt Whitman}

\subsection{To Samuel Hollyer}

ADDRESS: S Hollyer | artist | Guttenberg

New Jersey. POSTMARK: (?) | 8 PM | 88; (?) $\mid$ Au5 | (?).

Camden New Jersey | Aug 5'88

Thanks for the etching wh' has come safely-it seems to me very fine $-\&$ I shall probably write soon at greater length-

Walt Whitman

2076 To Charles W. Eldridge

Camden July 20'89

Dear C W E

Y'rs rec'd \& welcomed, as always - So you have flitted north on the Pacific coast \& settled in San Francisco. Good-no doubt- To use the N Y slang of low life I send you "good roots" for your new \& future habitat-

I am still holding out here-Probably better than you might suppose-but bad enough-physically almost completely disabledbrain, physique, locomotion, bladder business, digestion, \&c: \&c: all in pretty bad way - yet I sit up, read and write (moderately) \& get out doors in a propelled chair \& keep good spirits-

Nothing very significant in my literary affairs-hardly any salespoor dear W O'C[onnor] he has left by his death a great blank to me too-I just mailed his little last book "Donnelly's Reviewers" to John 
Burroughs, who is temporarily at Hobart N Y \& is well as usual- Hot spell here - three weeks - to day bad-I hear f'm Dr Bucke often-Mrs O' C (I fear by accounts) is left with very little financially - spent an hour down by the Delaware river side in my wheel chair-

Walt Whitman

\subsection{To Louisa Orr Whitman}

Camden near noon Oct: 31 '89

\section{Dear Lou}

The enclosed came last night-I had some of the chicken for my supper \& found it very nice-Am sitting here at present in my big wheel chair in my den-My sailor boy Warren is making up the bed.-

I am ab't as usual-cloudy \& looking like rain out-Mrs: D[avis] has gone out to Doylestown, Pa. to see an old couple-to be back this evn'g-had buckwheat cakes \& honey for breakfast-Hope you \& George are having good times-

Walt Whitman

2174.5 To John Burroughs

Mickle St Camden | Jan: 9 '90

\section{Dear J B}

This will be given you by my friend Felix Adler \& I hope you will have a good talk \& good time anyhow. Nothing very new or different with me-all is going on the same, \& fairly- Write, and when you do tell me your P[ost office] address \& any proposed movements -

Walt Whitman 
Dear friend ( $\&$ the baby too)

I have seen in the paper ab't your great affliction \& sympathize with you deeply-enclosed I send $\$ 5$ for you for the baby, \& come \& see me when convenient $\&$ bring the little one with you-

Walt Whitman

Mrs: Colquitt

2278.1 To David McKay

[8.19. 1890]

will sell you the above-described at three dollars (\$3) each copy$\$ 150$ cash for the 50

Walt Whitman

328 Mickle st

Camden N J

2365.1 To the Editor, The Critic

ADDRESS: Editor, Critic | 52 Lafayette Place

New York City. POSTMARK: Camden, N.J. | Nov 25 | $430 \mathrm{PM} \mid 90$.

Camden N J Nov: 25 '90

Wonder whether you care for this 9 for your announcem'ts? Whitman

The late Wm D. O'Connor, of Washington, D.C., left unpublished the MS: of "the Brazen Android," a tale, which with other new and some other stories including "the Carpenter" will be issued in book form. It is to have a brief prefatory note by Walt Whitman. 
Just tho't I'd send you a line as I sit here late at night Dec: 31 '90 in my Mickle st. den - hope you are pleasantly occupied \& will have a happy time to-morrow \& long following. Nothing very new or different with me-still hold out here, dropping a peg every month or so.

Jan: 1 '91-It has arrived here but in the shape of a dark stormy mn'g but it will soon clear

Walt Whitman

2408.1 To Hezekiah Butterworth

Jan: 2 '91

Dear Mr B-Can you use this in the Companion? - The price is $\$ 8$ and a dozen numbers of the paper containing it-and I reserve the right of printing in future book-

Very respectfully

\author{
Walt Whitman \\ 328 Mickle street \\ Camden New Jersey
}

2535.5 To Alexander Black

Camden N J May 12 |'91

Couldn't remember distinctly enough to authenticate the desk (the pict: hereby return'd as your note seems to involve) - but I know I had a good time in the Times - \& heartily send my best respects \& love to the boys one \& all now there-I send my last photo: Tack it up if you like on the wall you all most congregate.

Walt Whitman 